\title{
Pensonomonoor
}

2014, vol. 72, 103-111

http://dx.doi.org/10.12657/denbio.072.009

\author{
Łukasz Łuczaj, Artur Adamczak, Magdalena Duda
}

\section{Tannin content in acorns (Quercus spp.) from Poland}

Received: 19 November 2013; Accepted: 20 May 2014

\begin{abstract}
Oak acorns used to be an important human food, up until recent times. The major factor inhibiting their use in modern nutrition is their high tannin content. Polish oak trees were screened in order to find out whether there are any major geographical or interspecific differences in tannin and total phenolic contents in acorns, which might help us to establish further directions in the search for low-tannin individuals. We studied the level of phenolic compounds using the standard Polish and European Pharmacopoeia method, with Folin-Ciocalteu reagent and hide powder. Altogether 49 acorn samples of Quercus robur, 13 of Q. petraea, 1 of Q. pubescens (all native) and 12 of Q. rubra (introduced) were collected in different regions of Poland. The amount of investigated phenolics in Q. robur and Q. petraea acorns was similar, and tannins constituted the main component. The $Q$. pubescens sample was distinguished by the lowest tannin and total phenolic content and a relatively high amount of non-tannin phenolics. Q. rubra had a slightly lower tannin content than $Q$. robur and $Q$. petraea acorns, but the level of other phenolics was much higher. The results for Q. robur suggest geographical variability of phenolic content as well as a relationship between the phytochemical and biometric parameters of oak acorns.
\end{abstract}

Additional key words: polyphenols, oak acorns, phytochemistry, food security

Addresses: Ł. Łuczaj, University of Rzeszów, Institute of Applied Biotechnology and Basic Sciences, Department of Botany, Werynia 502, 36-100 Kolbuszowa, Poland, e-mail: lukasz.luczaj@interia.pl A. Adamczak, Institute of Natural Fibres and Medicinal Plants, Department of Botany, Breeding and Agricultural Technology, Kolejowa 2, 62-064 Plewiska near Poznań, Poland

M. Duda, University of Rzeszów, Institute of Applied Biotechnology and Basic Sciences, Department of Botany, Werynia 502, 36-100 Kolbuszowa, Poland

\section{Introduction}

Oaks (Quercus spp.) are one of the key species in temperate ecosystems in the Northern hemisphere. They not only harbor a large fauna of invertebrates, which feed on their leaves and acorns (Southwood 1961; Kennedy and Southwood 1984), but they have constituted one of the most sought after sources of calories for vertebrates (e.g. boar, rodents, jays etc.) and for humans in foraging economies (Maurizio 1927; Bainbridge 1986; Johns and Duquette 1991; Mason 1995, 2000; Massei et al. 1996; Moerman 1998; Mason and Nesbitt 2009; Turner et al. 2011). Oak acorns were also used as emergency food in war times in societies, which had previously abandoned their use. Oak kernels (Quercus semen), especially roasted ones (Quercus semen tostum), were also applied in traditional medicine throughout Europe 
(e.g. Paluch 1984; Rakić et al. 2007). Their past importance in human and animal nutrition, as well as in phytotherapy, has caused some interest in their chemical composition (Ofcarcik and Burns 1971; Cantos et al. 2003; Rakić et al. 2004, 2005, 2006, 2007; Kobs 2008).

The limiting factor in the use of acorns in human and animal nutrition is their high tannin content (Smallwood and Peters 1986; Rakić et al. 2007; Pour et al. 2010). Plant raw materials with high levels of tannins are widely used in phytotherapy, and they show antibacterial, astringent, antihemorrhagic and antidiarrhoeal properties. Internally, they are used to treat catarrh in the intestines and stomach (e.g. oak bark), as well as diarrhea (Kozłowski et al. 2009), but in large quantities, tannins are toxic to humans and disturb the ingestion of nutrients from the digestive tract (Chung et al. 1998). At high concentrations, tannins can also damage the gut epithelium and liver and kidney tissues (Singleton and Kratzer 1973; Chung-MacCoubrey et al. 1997). Finally, tannins at high levels can incur metabolic costs because of increased detoxification requirements (Chung-MacCoubrey et al. 1997). High levels of tannins also give food a bitter taste, making it unattractive for consumption. Some indigenous methods of removing tannins from acorns, or at least decreasing tannin content, have been described (Moerman 1998). These are soaking in running water, leaching, and cooking with clay as an adsorbent. In Poland and other Eastern European countries, acorns were commonly used to make a coffee substitute until the mid- $20^{\text {th }}$ century, and this tradition is reviving now (e.g. Łuczaj 2008; Dénes et al. 2012; Kalle and Sõukand 2012). They were also commonly used as an admixture to flour to make bread, but only within the context of food scarcity (Maurizio 1927; Łuczaj and Szymański 2007; Łuczaj 2008). Within Europe, acorns had much more importance in the Mediterranean than in northern Europe. In some parts of the Mediterranean, such as Spain and Sardinia, the acorns of Q. ilex L. are still eaten even nowadays (Johns and Duquette 1991; Tardío et al. 2006; Pignone and Laghetti 2010), and the use of roasted Q. virgiliana (Ten.) Ten. acorns was also recorded in southern Italy (Pieroni et al. 2005), whereas in northern Europe, where Q. robur is the commonest species, they have been forgotten even as famine food (Euczaj 2011; Dénes et al. 2012; Kalle and Sõukand 2012; Łuczaj et al. 2012). It is not unlikely that their larger importance in the south stems from the fact that $Q$. ilex, $Q$. virgiliana and $Q$. pubescens, the commonest oaks in the Mediterranean, are perceived as sweeter and less bitter than $Q$. robur, the dominant species in northern Europe. Additionally, Mazuelos Vela et al. (1967) found a very low tannin content in $Q$. ilex acorns (0.4-0.5\%). The acorns of Quercus have also been used as food in Asia (Pember- ton and Lee 1996; Hu 2005; Kang et al. 2012, 2013). As oaks are often components of climax vegetation, growing varieties of native oaks for food could enable food production in semi-natural woodlands. However, oaks are slow-growing plants, thus it is difficult to produce new cultivars. Intraspecific variability in the content of secondary plant metabolites is widespread in nature (e.g. Sidjimova et al. 2011; Adamczak et al. 2012a; Mirgos et al. 2012; O’Reilly-Wapstra 2013), and perceived by animals as they make their feeding choices (Smallwood and Peters 1986; Kimball et al. 2012). Phytochemical differentiation, even in closely related species, is also very widespread (e.g. Nowak 2005; Adamczak 2012b; Çaliskan et al. 2012; Edwards et al. 2012). There is quite a lot of data on tannin content in oak acorns in North America (Trimble 1896; Ofcarcik and Burns 1971; Fleck and Layne 1990; see also Mason 1992 for an overview of some of these papers), although very few such studies were performed in Europe (Rakić et al. 2004, $2005,2006,2007)$, and the tannin content of many common species (e.g. Q. petraea) has never been studied before. No screening of oak populations has been performed on a larger scale to study the natural variation in their levels of tannins. All previous studies of oak acorns were limited to samples from one or few localities. Our aim was to fill this gap and study the diversity of tannin and total phenolic content in acorns originating from Poland.

Only two native species of oaks and one exotic taxon are common in Poland. The English oak (Q. robur L.) can be found in all parts of Poland, except for higher elevations, and it is very common in a variety of habitats, from dry to moist. It is both an important forestry tree and a component of parks and gardens. The sessile oak (Q. petraea (Matt.) Liebl., syn. Q. sessilis Ehrh.) occurs mainly in the lowlands, except for some parts of NE Poland. It is not as common as the English oak, and only occasionally becomes sub-dominant in forests. This species is mainly restricted to drier habitats, where it usually grows together with Scots pine (Pinus sylvestris) or English oak. The third taxon of oak, the pubescent oak (Q. pubescens Willd.), can be found only in one small location in NW Poland, in the Odra valley (Chybicki et al. 2012). It is a sub-Mediterranean species widely distributed in southern and south-central Europe, mainly in calcareous soils. All three native oaks belong to the Quercus subgenus (=Lepidobalanus Endl. pro parte) and Quercus section (Boratyński et al. 2006). After the English oak, the second most common oak species in Poland is the introduced red oak (Q. rubra L.), extensively planted in forests and parks and often naturalized.

As oaks of the subgenus of Erythrobalanus (Spach) Oerst. (e.g. Q. rubra) are regarded as more bitter than other oaks (e.g. Ofcarcik and Burns 1971), our hypothesis was that the introduced $Q$. rubra would have 
the most bitter acorns. In North America the mean content of tannins found in the Erythrobalanus oaks ("red oaks") was $9.8 \%$ (ranging from 2.9 to 20.3\%), and in Lepidobalanus oaks ("white oaks") it was $7.0 \%$ (ranging from 3.3 to 10.9\%) (Mason 1992). However we also assumed that some differences would be found between $Q$. robur and $Q$. petraea, or between geographical races/forms of $Q$. robur.

\section{Material and Methods}

\section{Plant material}

Oak acorns were collected, in October and November 2011 and 2012, from under individual trees. For each sample 20-30 acorns were usually taken, airdried at room temperature $\left(23-25^{\circ} \mathrm{C}\right)$, then shelled out and powdered. For phytochemical analysis, oak kernels - seeds (Quercus semen) were used. A variety of measurements were also made (weight before and after air-drying, and after shelling, as well as length and width) for acorns collected in 2012. Altogether, 49 acorn samples of Quercus robur, 13 of Q. petraea, 1 of $Q$. pubescens and 12 of $Q$. rubra were collected in various parts of Poland (Fig. 1, Appx 1). As most of our Q. robur samples came either from western or south-eastern Poland, we compared these two groups of localities in some of our analyses (Fig. 1). The single sample of $Q$. pubescens (which is extremely rare in Poland) was collected from the Adam Mickiewicz University Botanical Garden in Poznań, from a tree originating from the only native population of this species in Poland (from the Bielinek reserve).

\section{Phytochemical analysis}

Phytochemical analysis was conducted according to the Polish and European Pharmacopoeia (2006, 2008,2010 ). Binding by raw hide was used as a way of determining tannin content. Use of collagen-rich raw hide powder is an easy way to estimate the level of tannins, due to their protein-binding properties (Seigler et al. 1986). The amounts of total polyphenols (phenolics) and polyphenols unadsorbed on hide powder (non-tannin phenolics) were determined spectrophotometrically with Folin-Ciocalteu reagent, for $1.0 \mathrm{~g}$ of air-dried, powdered oak seeds after 30 min of hot water extraction in a water bath. The absorbance was measured at $\lambda=760 \mathrm{~nm}$. The tannin content (expressed as pyrogallol equivalent) was calculated as the difference between total phenolics and non-tannin phenolics (Rakić et al. 2006; Adamczak et al. 2012a). The obtained results were calculated for dry matter $(D M)$. The moisture content [\%] in the raw material was measured after drying it at $105^{\circ} \mathrm{C}$ to constant mass. Folin-Ciocalteu reagent and sodium carbonate decahydrate were purchased from POCh. Pyrogallol (1,2,3-trihydroxybenzene) and hide powder were obtained from Sigma-Aldrich.

All analytical procedures were performed with protection from light. Acorn samples were extracted with $150 \mathrm{ml}$ of water for $30 \mathrm{~min}$ in a boiling water bath, then the flask with extract was cooled and made up with water to $250 \mathrm{ml}$. After the sedimentation of plant material, the water extract was filtered, and the first $50 \mathrm{ml}$ of filtered liquid was rejected. Total polyphenols were determined from $5 \mathrm{ml}$ of filtrate diluted with water to $25 \mathrm{ml}$. To $2 \mathrm{ml}$ of this solution $1 \mathrm{ml}$ of Folin-Ciocalteu reagent was added, then $10 \mathrm{ml}$ of water, and the flask was filled up to $25 \mathrm{ml}$ with sodium carbonate solution $(290 \mathrm{~g} / \mathrm{l})$. The absorbance was measured after 30 min of incubation in darkness, using water for compensation. The content of non-tannin phenolics was determined from $10 \mathrm{ml}$ of filtrate with addition of $0.1 \mathrm{~g}$ hide powder, after shaking (60 $\mathrm{min}$ ) and filtering of the solution. From this solution, $5 \mathrm{ml}$ was made up with water to $25 \mathrm{ml}$ and the further procedure was repeated as above. The reference standard solution was prepared from $50 \mathrm{mg}$ pyrogallol in water diluted up to $100 \mathrm{ml}$. Afterwards, $5 \mathrm{ml}$ of this solution was diluted with water to $100 \mathrm{ml}$, and 2 $\mathrm{ml}$ was used for further analysis with Folin-Ciocalteu reagent, as described above. The tannin content (\%) was calculated with the following formula:

$$
X=62.5 \times\left(A_{1}-A_{2}\right) \times m_{2} / A_{3} \times m_{1}
$$

where: $\mathrm{X}$ - tannin content; $\mathrm{A}_{1}$ - absorbance of total phenolics; $A_{2}$ - absorbance of phenolics unadsorbed on hide powder; $\mathrm{A}_{3}$ - absorbance of reference solution of pyrogallol; $\mathrm{m}_{1}$ - mass of investigated sample [g]; $\mathrm{m}_{2}$ - mass of pyrogallol [g].

\section{Statistical analysis}

The Shapiro-Wilk test was applied to check the normality of variable distribution, and F-test and Levene's test were used to analyse the homogeneity of variances. For the skewed distribution of variables, square root, logarithmic and inverse proportion transformations of data were performed. In the analysis of intra- and interspecific differences, Student, Mann-Whitney and Kruskal-Wallis tests were used. Pearson's correlation and Spearman's rank correlation were applied to evaluate the relationships between variables. An open access statistical program PAST (Hammer et al. 2001; PAST 2012) and Statistica 7.1 software (Statistica 2005) were used for analyses. 


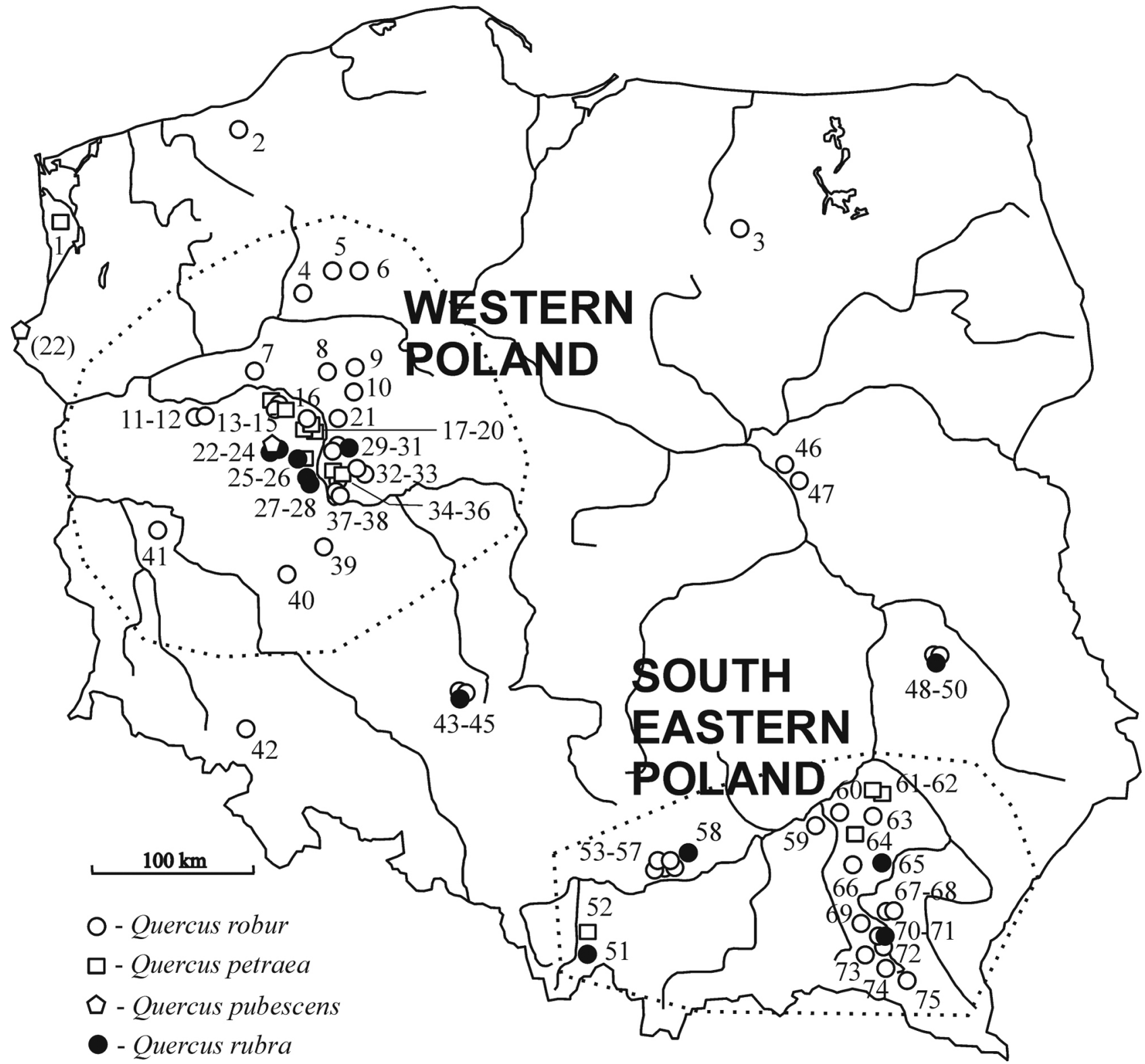

Fig. 1. Distribution of acorn samples

1 - Police near Szczecin (Q. petraea), 2 - Strzekęcino near Koszalin (Q. robur), 3 - Tylkowo near Olsztyn (Q. robur), 4 - Skórka near Piła (Q. robur), 5 - Śmiardowo Złotowskie near Złotów (Q. robur), 6 - Dorotowo near Złotów (Q. robur), 7 - Klempicz near Czarnków (Q. robur), 8 - Gościejewo near Rogoźno (Q. robur), 9 - Wagrowiec (Q. robur), 10 - Roszkowo near Wagrowiec (Q. robur), 11-12 - Międzychód (Q. robur), 13 - Obrzycko near Szamotuły (Q. petraea), 14-15 - Obrzycko near Szamotuły (Q. robur), 16 - Jaryszewo near Szamotuły ( $Q$. petraea), 17 - Biedrusko near Poznań (Q. robur), 18-20 - Biedrusko near Poznań (Q. petraea), 21 - Zielonka near Poznań (Q. robur), 22 Adam Mickiewicz University Botanical Garden in Poznań (Q. pubescens), (22) - the Bielinek reserve (the original locality of Q. pubescens), 23-24 - Adam Mickiewicz University Botanical Garden in Poznań (Q. rubra), 25 - Dendrological Garden of University of Life Sciences in Poznań (Q. rubra), 26 - Dendrological Garden of University of Life Sciences in Poznań (Q. petraea), 27-28 - Poznań Stare Miasto (Q. rubra), 29-30 - Poznań Nowe Miasto (Q. robur), 31 - Poznań Nowe Miasto (Q. rubra), 32-33 - Koninko near Poznań (Q. robur), 34-35 - Daszewice near Poznań (Q. petraea), 36 - Daszewice near Poznań (Q. robur), 37-38 - Rogalin near Mosina (Q. robur), 39 - Dusina near Gostyń (Q. robur), 40 - Bojanowo near Leszno (Q. robur), 41 - Zielona Góra (Q. robur), 42 - Modlęcin near Świebodzice (Q. robur), 43-44 - Bąków near Kluczbork (Q. robur), 45 - Bąków near Kluczbork (Q. rubra), 46 - Warszawa Rembertów (Q. robur), 47 - Pilawa near Warszawa (Q. robur), 48 - Lublin Śródmieście (Q. robur), 49 - Lublin Konstantynów (Q. robur), 50 - Lublin Konstantynów (Q. rubra), 51 - Porąbka near Bielsko-Biała (Q. rubra), 52 - Kęty near Bielsko-Biała (Q. petraea), 53-54 - Kraków Bronowice (Q. robur), 55 - Kraków Czyżyny (Q. robur), 56 - Kraków Grzegórzki (Q. robur), 57 - Kraków Stare Miasto (Q. robur), 58 - Raciborowice near Kraków (Q. rubra), 59 - Suchy Grunt near Mielec (Q. robur), 60 - Mielec (Q. robur), 61-62 - Nowa Dęba (Q. petraea), 63 - Werynia near Kolbuszowa $(Q$. robur), 64 - Leszcze near Kolbuszowa (Q. petraea), 65 - Rzeszów (Q. rubra), 66 - Gnojnica near Ropczyce (Q. robur), 67-68 - Rzepnik near Krosno (Q. robur), 69 - Ustrobna near Krosno (Q. robur), 70 - Krosno (Q. robur), 71 - Krosno (Q. rubra), 72 - Haczów near Krosno (Q. robur), 73 - Chorkówka near Krosno (Q. robur), 74 - Wróblik Królewski near Krosno (Q. robur), 75 - Mymoń near Krosno (Q. robur). Geographical coordinates of acorn samples - Appx 1. 
Table 1. Size and weight variability of oak acorns collected in 2012 (mean as well as minimum and maximum given in brackets)

\begin{tabular}{lccc}
\hline \multicolumn{1}{c}{ Variables $\backslash$ Species } & Q. robur $(\mathrm{n}=36)$ & Q. petraea $(\mathrm{n}=11)$ & Q. rubra $(\mathrm{n}=9)$ \\
\hline acorn length [cm] ${ }^{* * *}$ & $2.71(2.26-3.66)$ & $2.63(1.96-3.06)$ & $2.14(1.98-2.28)$ \\
acorn width [cm $]^{* * *}$ & $1.48(1.16-1.73)$ & $1.56(1.32-1.85)$ & $1.87(1.75-2.02)$ \\
length/width of acorns*** & $1.83(1.48-2.23)$ & $1.69(1.48-1.81)$ & $1.14(1.02-1.21)$ \\
air-dry weight of acorns [g] & $3.15(1.16-5.32)$ & $3.12(1.36-4.39)$ & $3.86(3.09-4.57)$ \\
air-dry weight of seeds [g] $^{\text {N.S. }}$ & $2.63(0.85-4.55)$ & $2.52(1.05-3.33)$ & $2.39(1.98-2.82)$ \\
seed share in the acorn weight [\%] ${ }^{* * *}$ & $83(73-87)$ & $81(75-85)$ & $62(55-68)$ \\
\hline
\end{tabular}

The length and width of acorns were determined on the basis of 20-30 measurements for each sample, while the weight of acorns and seeds - on the basis of one measurement for the whole sample. Kruskal-Wallis test for interspecific differentiation of the size and weight of acorns: N.S. - not significant $(p>0.05) ;^{*}-p<0.05 ;{ }^{* * *}-p<0.001 ; \mathrm{n}=56$.

\section{Results}

Our research showed that oak acorns lose about $30 \%$ of their weight after air-drying, then acorn shells contain an average of $6.9 \%$ water, and acorn kernels (seeds) $-6.4 \%$. Acorns of Q. robur (English oak) and $Q$. petraea (sessile oak) were characterized by a high variability of size and weight, but they did not differ from each other. Acorns of Q. rubra (red oak) were significantly different from the oak species native to Poland, and they showed a low variation in size and weight. It is interesting that the percentage share of seeds at the air-dry weight of Q. rubra acorns was significantly lower than in the case of $Q$. robur and $Q$. petraea acorns. Although Q. rubra acorns were on average heavier than those of the native oaks, their mean seed mass was slightly lower than that of the native species (Table 1). The investigated samples of oak acorns indicated a wide range of phytochemical variability. $Q$. pubescens acorns were distinguished by the lowest content of total phenolics $(2.61 \% D M)$ and tannins $(0.97 \%)$, and by a relatively high amount of non-tannin phenolics (1.64\%). The level of total phenolics and tannins in the case of other species did not differ significantly. Tannins, especially for Q. robur and Q. petraea acorns, constituted the main component of polyphenols. Attention should be paid to the relatively low tannin content of $Q$. rubra acorns in relation to the level of non-tannin phenolics (Table 2 ). The total amounts of phenolics and tannins in Q. robur acorns collected in 2012 were significantly higher in SE Poland compared to W Poland. The geographical origin of samples did not affect the content of non-tannins or the ratio of tannins to non-tannins. Acorns from western Poland were characterized by a slightly larger average size and weight, but these differences were not statistically significant (Table 3).

For $Q$. robur we found negative correlations between the size and weight of acorns and the level of the investigated groups of active compounds, but these correlations were not strong. The highest correlation was detected between the total level of phenolics and the air-dry weight of acorn seeds. Tannin content was most strongly associated with seed weight. In the case of the level of non-tannins, the highest correlation was found with acorn width. On the other hand, the ratio of tannins to non-tannins was not connected with the size and weight of $Q$. robur acorns. Similarly, the shape index of acorns (length/width) was not correlated with the amount of chemical compounds (Table 4).

\section{Discussion}

Our biometric studies of acorns indicate a high variability of $Q$. robur and $Q$. petraea, and lower differentiation of $Q$. rubra (Table 1). According to the literature, both native species are characterized by a large morphological variation. The length of $Q$. robur acorns ranges from 1.5 to $4.0 \mathrm{~cm}$, width: $1.0-2.0$ $\mathrm{cm}$ and weight: $2.00-6.90 \mathrm{~g}$. In the case of Q. petraea acorns it is: $1.6-3.5 \mathrm{~cm}, 0.8-1.6 \mathrm{~cm}$ and $1.54-7.58$ g, respectively (Boratyńska et al. 2006). The smaller variability of $Q$. rubra from Poland may be due to the fact that it is an alien species (the so-called "founder

Table 2. Mean content of total phenolics, tannins and non-tannin phenolics in the seeds of oak acorns collected in the years 2011-2012 (the minimum and maximum given in brackets)

\begin{tabular}{llll}
\hline \multicolumn{1}{c}{ Variables $\backslash$ Species } & Q. robur $(\mathrm{n}=49)$ & Q. petraea $(\mathrm{n}=13)$ & Q. rubra $(\mathrm{n}=12)$ \\
\hline total phenolics [\% DM] ${ }^{\text {N.S. }}$ & $4.33(3.05-6.58)$ & $4.29(3.36-6.66)$ & $4.58(3.48-5.80)$ \\
tannins [\% DM] $]^{\text {N.S. }}$ & $3.48(2.43-5.17)$ & $3.39(2.57-4.75)$ & $2.97(2.10-4.26)$ \\
non-tannins [\% DM] ${ }^{* * *}$ & $0.86(0.57-1.89)$ & $0.90(0.58-2.06)$ & $1.60(1.29-2.00)$ \\
tannins/non-tannins*** & $4.25(1.84-6.26)$ & $4.39(1.25-5.98)$ & $1.90(1.19-2.77)$ \\
\hline
\end{tabular}

Total phenolics, tannins and non-tannins - expressed as pyrogallol equivalent; tannins/non-tannins - the ratio of tannins to non-tannins; DM - dry matter of raw material. Kruskal-Wallis test for interspecific differentiation of the content of phenolic compounds (without $Q$. pubescens): N.S. - not significant $(\mathrm{p}>0.05){ }^{* * *}-p<0.001 ; \mathrm{n}=74$. 
Table 3. Differentiation of the polyphenol content and the biometric parameters of Quercus robur acorns collected in 2012 from sides in two regions of Poland (mean \pm SD)

\begin{tabular}{lccc}
\hline \multicolumn{1}{c}{ Variables } & Western Poland & South-Eastern Poland & $p$-value \\
\hline total phenolics [\% DM] $^{\text {a }}$ & $3.89 \pm 0.45$ & $4.35 \pm 0.45$ & 0.0127 \\
tannins [\% DM] & $3.15 \pm 0.39$ & $3.56 \pm 0.45$ & 0.0146 \\
non-tannins [\% DM] $^{\text {a }}$ & $0.74 \pm 0.12$ & $0.78 \pm 0.12$ & 0.3677 \\
tannins/non-tannins $^{\mathrm{b}}$ & $4.32 \pm 0.67$ & $4.67 \pm 0.93$ & 0.3627 \\
acorn length [cm] $^{\text {a }}$ & $2.75 \pm 0.27$ & $2.67 \pm 0.26$ & 0.4360 \\
acorn width [cm] $^{\text {a }}$ & $1.52 \pm 0.12$ & $1.47 \pm 0.11$ & 0.3021 \\
length/width of acorns $^{\mathrm{a}}$ & $1.81 \pm 0.13$ & $1.82 \pm 0.20$ & 0.8823 \\
air-dry weight of acorns [g] $^{\mathrm{a}}$ & $3.28 \pm 0.73$ & $3.15 \pm 0.56$ & 0.5901 \\
air-dry weight of seeds [g] $^{\mathrm{a}}$ & $2.76 \pm 0.61$ & $2.62 \pm 0.52$ & 0.5126 \\
seed share in the acorn weight [\%] $^{\mathrm{b}}$ & $84 \pm 1.8$ & $83 \pm 2.4$ & 0.2737 \\
\hline
\end{tabular}

Total phenolics, tannins and non-tannins - expressed as pyrogallol equivalent; DM - dry matter of raw material; SD - standard deviation. Statistical tests: $\mathrm{a}$ - Student's test; $\mathrm{b}$ - Mann-Whitney test; $\mathrm{n}=28$.

effect", or "bottle-neck effect"). The high similarity of acorn size and weight, as well as phenolic content, in $Q$. robur and $Q$. petraea (Table 1-2) confirms that both species belong to one section and subsection of Quercus and are closely related (Boratyński et al. 2006). As expected, the acorns of Q. pubescens (Galliferae subsection), were low in tannin content, however not as low as Q. ilex (Mazuelos Vela et al. 1967). On the other hand it was surprising that $Q$. rubra acorns were not characterized by a higher level of tannins than $Q$. robur and Q. petraea (Table 2). The oaks of the Erythrobalanus subgenus, to which the red oak $(Q$. rubra) belongs, are generally regarded as more bitter and tannin-rich than other oaks (Ofcarcik and Burns 1971; Weckerly et al. 1989; Mason 1992).

The obtained results of phytochemical investigations are difficult to compare with the literature data, due to different methods of drying, extraction and analysis of acorn samples. Tannins are a very versatile group of usually polymeric compounds, and different analytical methods may exclude or include certain subgroups of this category of compounds. We used the hide powder method, as it is widely used in many countries (Seigler 1986; Rakić et al. 2006; Kobs 2008), although detailed procedures varied between the studies.

According to Rakić and coauthors (2005, 2006, 2007), the tannin content in $Q$. robur acorns varies, depending on the method of drying and extraction of samples, from 7.76 to $20.4 \%$. It is interesting that the ratio of tannins to non-tannins was similar to our results (Table 2) and ranged from 2.78 to 10.73 (Rakić et al. 2006, 2007). On the other hand, Smallwood and Peters (1986) indicate that the tannin level in the white oak group Lepidobalanus is much lower and ranges from 0.5 to $2.5 \%$. Pour et al. (2010) also show a low level of tannins in oak kernels (1.76\%). Older American studies of acorn composition usually report larger tannin contents, which may be the result of different procedures used in analyses.
Comparative analysis of $Q$. robur samples collected in one year from western and south-eastern Poland showed significant differences in the total content of phenolics and tannins between these regions (Table 3 ). This may indicate the geographical variability of the level of investigated chemical compounds in oak acorns. It was interesting that these samples were different, although only slightly, in terms of size and weight, too (Table 3). Therefore, the relations between phytochemical and biometric parameters of $Q$. robur acorns were studied (Table 4). The results obtained suggest that the amount of polyphenols is connected with the size and weight of acorns. This may be a clue towards the gathering of lower tannin fruits. However, it is important to find out whether this phenomenon is caused by the fact that oaks growing in better habitat (climatic) conditions produce larger and lower-tannin acorns or whether genetic factors are responsible for this relationship.

Further research on the tannin content of south European oak acorns should be carried out in order to find out whether the larger popularity of acorns as food in southern Europe rather than in the north stems from differences in tannin and polyphenol contents. This hypothesis is supported by the low tannin content of $Q$. pubescens acorns, originating from the only native Polish population of this species (Table 2 ), and in the case of some samples of Q. ilex (Mazuelos Vela et al. 1967 cited by Mason 1992). We pro-

Table 4. Correlation between the polyphenol content and the biometric parameters of Quercus robur acorns

\begin{tabular}{lccc}
\hline \multicolumn{1}{c}{ Variables } & $\begin{array}{c}\text { total } \\
\text { phenolics }\end{array}$ & tannins & $\begin{array}{c}\text { non- } \\
\text { tannins }\end{array}$ \\
\hline acorn length $^{\mathrm{a}}$ & $-0.37^{*}$ & $-0.33^{*}$ & \\
acorn width $^{\mathrm{a}}$ & $-0.44^{* *}$ & $-0.38^{*}$ & $-0.43^{* *}$ \\
air-dry weight of acorns $^{\mathrm{a}}$ & $-0.45^{* *}$ & $-0.42^{*}$ & $-0.38^{*}$ \\
air-dry weight of seeds $^{\mathrm{a}}$ & $-0.48^{* *}$ & $-0.44^{* *}$ & $-0.39^{*}$ \\
seed share in the acorn weight $^{\mathrm{b}}$ & & & $-0.39^{*}$ \\
\hline
\end{tabular}

$\mathrm{a}$ - Pearson's correlation; $\mathrm{b}$ - Spearman's rank correlation; $p$-value: ${ }^{* * *}-p<0.001,{ }^{* *}-p<0.01,{ }^{*}-p<0.05, \mathrm{n}=36$. 
pose further research into the chemistry and nutritional value of acorns, as oaks have been key species during food crises in temperate and Mediterranean climates and have huge potential as food plants, both as emergency food and an alternative major source of starch. This is proven by the fact that the Dary Natury company (from Koryciny, NE Poland) sells large amounts of tannin-deprived $Q$. robur flour in health food shops in Poland. A tannin removal technique (the firm's secret) was developed by Mr Mirosław Angielczyk, the owner of the company (http://www. ziolowyzakatek.sklep.pl/maka.z.zoledzi.eko.1 kg. dary.natury.html). As oaks harbor a rich insect flora, and acorns are very susceptible to insect and pathogen invasions, another branch of oak research should be the study of tannin-removal techniques. Efficient tannin removal from acorns may be a more economically viable option than growing low-tannin cultivars.

\section{Acknowledgments}

The authors would like to thank Prof. Waldemar Buchwald for sharing his laboratory and to Hanna Zalińska (Institute of Natural Fibres and Medicinal Plants in Poznań) - for her help with phytochemical analysis. We thank Prof. Justyna Wiland-Szymańska (Adam Mickiewicz University Botanical Garden in Poznań) and Dr. Tomasz Maliński (Dendrological Garden of University of Live Sciences in Poznań) for access to the garden to sample collecting. We would also like to thank the following persons for their help in collecting some of the acorn samples: Ms. Małgorzata Adamczak (Adam Mickiewicz University), Dr. Piotr Androsiuk (University of Warmia and Mazury in Olsztyn), Ms. Agnieszka Gryszczyńska (Institute of Natural Fibres and Medicinal Plants in Poznań), Dr. Alicja Kolasińska (Adam Mickiewicz University Botanical Garden in Poznań), Mr. Maciej Łochyński (Biotope, Poznań), Mr. Romuald Mordalski (Institute of Natural Fibres and Medicinal Plants in Poznań), Mr. Marek Podsiedlik (University of Live Sciences in Poznań), Mr. Przemysław Susek (Regional Inspectorate for Environmental Protection in Zielona Góra), Dr. Joanna Trubicka (Children's Memorial Health Institute in Warszawa) and Ms. Marika Węgrzynek (University of Rzeszów).

\section{References}

Adamczak A., Buchwald W., Gryszczyńska A. 2012a. Phytochemical variability of coltsfoot (Tussilago farfara L.) in Poland. Herba Polonica 58: 7-14.

Adamczak A., Buchwald W., Zieliński J., Mielcarek S. 2012b. Flavonoid and organic acid content in rose hips (Rosa L., section Caninae DC. em. Christ.). Acta Biologica Cracoviensia 54: 105-112.
Bainbridge D.A. 1986. The use of acorns for food in California: past, present, future. In: Proceedings of the Symposium on Multiple-use Management of California's Hardwood Resources. San Luis Obispo, pp. 453-458.

Boratyńska K., Filipiak M., Boratyński A. 2006. Budowa morfologiczna i zmienność. In: Dęby. Nasze Drzewa Leśne. Tom 11. Bugała W. (ed.). Instytut Dendrologii PAN, Poznań-Kórnik, pp. 63-85.

Boratyński A., Boratyńska K., Filipiak M. 2006. Systematyka i rozmieszczenie. In: Dęby. Nasze Drzewa Leśne. Tom 11. Bugała W. (ed.). Instytut Dendrologii PAN, Poznań-Kórnik, pp. 85-114.

Çaliskan O., Gündüz K., Serçe S., Toplu C., Kamiloglu Ö., Sengül M., Ercisli S. 2012. Phytochemical characterization of several hawthorn (Crataegus spp.) species sampled from the Eastern Mediterranean region of Turkey. Pharmacognosy Magazine 8: 1621. http://dx.doi.org/10.4103/0973-1296.93305

Cantos E., Espin J.C., Lopez-Bote C., de la Hoz L., Ordonez J.A., Tomas-Barberan F.A. 2003. Phenolic compounds and fatty acids from acorns (Quercus spp.), the main dietary constituent of freeranged Iberian pigs. Journal of Agricultural and Food Chemistry 51: 6248-6255. http://dx.doi. org/10.1021/jf030216v

Chung K.T., Wong T.Y., Wei C.I., Huang Y.W., Lin Y. 1998. Tannins and human health: a review. Critical Reviews in Food Science and Nutrition 38: 421-464. http://dx.doi. org/10.1080/10408699891274273

Chung-MacCoubrey A.L., Hagerman A.E., Kirkpatrick R.L. 1997. Effects of tannins on digestion and detoxification activity in gray squirrels (Sciurus carolinensis). Physiological Zoology 70: 270-277.

Chybicki I.J., Oleksa A., Kowalkowska K., Burczyk J. 2012. Genetic evidence of reproductive isolation in a remote enclave of Quercus pubescens in the presence of cross-fertile species. Plant Systematics and Evolution 298: 1045-1056. http://dx.doi. org/10.1007/s00606-012-0614-8

Dénes A., Papp N., Babai D., Czúcz B., Molnár Z. 2012. Wild plants used for food by Hungarian ethnic groups living in the Carpathian Basin. Acta Societatis Botanicorum Poloniae 81: 381-396. http://dx.doi.org/10.5586/asbp.2012.040

Edwards J.E., Brown P.N., Talent N., Dickinson T.A., Shipley P.R. 2012. A review of the chemistry of the genus Crataegus. Phytochemistry 79: 5-26. http:// dx.doi.org/10.1016/j.phytochem.2012.04.006

European Pharmacopoeia. 2010. 7th ed. CE, Strasbourg, pp. 243-244.

Farmakopea Polska. 2006. 7th ed., vol. I. Wyd. PTFarm, Warszawa, pp. 329-330.

Farmakopea Polska. 2008. 8th ed., vol. I. Wyd. PTFarm, Warszawa, p. 232. 
Fleck D.C., Layne J.N. 1990. Variation in tannin activity of acorns of seven species of central Florida oaks. Journal of Chemical Ecology 16: 2925-2934. http://dx.doi.org/10.1007/BF00979484

Hammer O., Harper D.A.T., Ryan P.D. 2001. PAST: paleontological statistics software package for education and data analysis. Paleontologia Electronica 4: 9 .

Hu S.Y. 2005. Food plants of China. The Chinese University Press, Hong Kong.

Johns T., Duquette M. 1991. Traditional detoxification of acorn bread with clay. Ecology of Food and Nutrition 25: 221-228. http://dx.doi.org/10.108 0/03670244.1991.9991170

Kalle R., Sõukand R. 2012. Historical ethnobotanical review of wild edible plants of Estonia (1770s-1960s). Acta Societatis Botanicorum Poloniae 81: 271-281. http://dx.doi.org/10.5586/ asbp.2012.033

Kang Y., Łuczaj Ł., Ye S., Zhang S., Kang J. 2012. Wild food plants and wild edible fungi of Heihe valley (Qinling Mountains, Shaanxi, central China): herbophilia and indifference to fruits and mushrooms. Acta Societatis Botanicorum Poloniae 81: 405-413. http://dx.doi.org/10.5586/ asbp.2012.044

Kang Y., Łuczaj Ł., Kang J., Zhang S. 2013. Wild food plants and wild edible fungi in two valleys of the Qinling Mountains (Shaanxi, central China). Journal of Ethnobiology and Ethnomedicine 9: 26. http://dx.doi.org/10.1186/1746-4269-9-26

Kennedy C.E.J., Southwood T.R.E. 1984. The number of species of insects associated with British trees: a re-analysis. Journal of Animal Ecology 53: 455-478. http://dx.doi.org/10.2307/4528

Kimball B.A., Russell J.H., Ott P.K. 2012. Phytochemical variation within a single plant species influences foraging behavior of deer. Oikos 121: 743-751. http://dx.doi.org/10.1111/j.16000706.2011.19515. $\mathrm{x}$

Kobs L. 2008. Dietary polyphenolic intake from acorns and acorn meal. Masters thesis, The University of Georgia, Athens.

Kozłowski J., Buchwald W., Forycka A., Szczygielska D. 2009. Rośliny i surowce lecznicze. IWNiRZ, Poznań, pp. 13-28.

Łuczaj Ł. 2008. Archival data on wild food plants used in Poland in 1948. Journal of Ethnobiology and Ethnomedicine 4: 4. http://dx.doi. org/10.1186/1746-4269-4-4

Łuczaj Ł. 2011. Dziko rosnące rośliny jadalne użytkowane w Polsce od połowy XIX w. do czasów współczesnych. Etnobiologia Polska 1: 57-125.

Łuczaj Ł., Pieroni A., Tardío J., Pardo-de-Santayana M., Sõukand R., Svanberg I., Kalle R. 2012. Wild food plant use in 21 st century Europe: the disappearance of old traditions and the search for new cuisines involving wild edibles. Acta Societatis Botanicorum Poloniae 81: 359-370. http://dx. doi.org/10.5586/asbp.2012.031

Łuczaj Ł., Szymański W.M. 2007. Wild vascular plants gathered for consumption in the Polish countryside: a review. Journal of Ethnobiology and Ethnomedicine 3: 17. http://dx.doi.org/10.1186/17464269-3-17

Mason S.L.R. 1992. Acorns in human subsistence. $\mathrm{PhD}$ thesis, Institute of Archaeology, University College, London.

Mason S. 1995. Acornutopia? Determining the role of acorns in past human subsistence. In: Food in Antiquity. Wilkins J., Harvey D., Dobson M. (eds). University of Exeter Press, Exeter, pp. 12-24.

Mason S. 2000. Fire and Mesolithic subsistence-managing oaks for acorns in northwest Europe? Palaeogeography, Palaeoclimatology, Palaeoecology 164: 139-150. http://dx.doi.org/10.1016/S00310182(00)00181-4

Mason S., Nesbitt M. 2009. Acorns as food in southeast Turkey: implications for prehistoric subsistence in Southwest Asia. In: From foragers to farmers: papers in honour of Gordon C. Hillman. Fairbairn A., Weiss E. (eds). Oxbow Books, Oxford, pp. 71-85.

Massei G., Genov P.V., Staines B.W. 1996. Diet, food availability and reproduction of wild boar in a Mediterranean coastal area. Acta Theriologica 41: 307-320. http://dx.doi.org/10.4098/ AT.arch.96-29

Maurizio A. 1927. Die Geschichte unserer Pflanzennahrung von den Urzeiten bis zur Gegenwart. Verlag Paul Parey, Berlin.

Mazuelos Vela F., Ramos Ayerbe F., Ros de Ursino, J.A.F. 1967. Le fruit du Chêne (Quercus ilex). Oléagineux 22: 169-171.

Mirgos M., Przybyszewska E., Capecka E., Angielczyk M., Przybył J.L., Bączek K., Węglarz Z. 2012. Intraspecific variability of great burnet (Sanguisorba officinalis L.) in respect of sterols content. Herba Polonica 58: 16-23.

Moerman D.E. 1998. Native American Ethnobotany. Timber Press, Portland.

Nowak R. 2005. Fatty acids composition in fruits of wild rose species. Acta Societatis Botanicorum Poloniae 74: 229-235. http://dx.doi.org/10.5586/ asbp. 2005.029

O’Reilly-Wapstra J.M., Miller A.M., Hamilton M.G., Williams D., Glancy-Dean N., Potts B.M. 2013. Chemical variation in a dominant tree species: population divergence, selection and genetic stability across environments. PLoS ONE 8: e58416. http://dx.doi.org/10.1371/journal.pone.0058416 Ofcarcik R.P., Burns E.E. 1971. Chemical and physical properties of selected acorns. Journal of 
Food Science 36: 576-578. http://dx.doi.org/10.1111/j.1365-2621.1971.tb15133.x

Paluch A. 1984. Świat roślin w tradycyjnych praktykach leczniczych wsi polskiej. Uniwersytet Wrocławski, Wrocław.

PAST version 2.17b: http://folk.uio.no/ohammer/ past, accessed 15 Nov 2012.

Pemberton R.W., Lee N.S. 1996. Wild food plants in South Korea; market presence, new crops, and exports to the United States. Economic Botany 50: 57-70. http://dx.doi.org/10.1007/BF02862113

Pieroni A., Nebel S., Santoro R.F., Heinrich M. 2005. Food for two seasons: culinary uses of non-cultivated local vegetables and mushrooms in a south Italian village. International Journal of Food Sciences and Nutrition 56: 245-272. http://dx. doi.org/10.1080/09637480500146564

Pignone D., Laghetti G. 2010. On sweet acorn cake (Quercus spp.) tradition in Italian cultural and ethnic islands. Genetic Resources and Crop Evolution 57: 1261-1266. http://dx.doi.org/10.1007/ s10722-010-9625-X

Pour M.B., Bahmaninia E., Ebrahimi R., Fayazi J. 2010. Evaluate effects of different inclusion of oak kernel with determine food potential oak kernel substitute with corn seed on broiler chicken's ration. Research Journal of Biological Sciences 5: 17 19. http://dx.doi.org/10.3923/rjbsci.2010.17.19

Rakić S., Maletić R., Perunović M., Svrzić G. 2004. Influence of thermal treatment on tannin content and antioxidation effect of oak acorn Quercus cerris extract. Journal of Agricultural Sciences 49: 97-107.

Rakić S., Petrović S., Kukić J., Jadranin M., Tešević V., Povrenović D., Šiler-Marinković S. 2007. Influence of thermal treatment on phenolic compounds and antioxidant properties of oak acorns from Serbia. Food Chemistry 104: 830-834. http://dx.doi. org/10.1016/j.foodchem.2007.01.025

Rakić S., Povrenović D., Maletić R., Živković M. 2005. Drying of the aqueous extract of acorn Quercus robur in a spouted-fluid bed. Journal of Agricultural Sciences 50: 173-182.

Rakić S., Povrenović D., Tešević V., Simić M., Maletić R. 2006. Oak acorn, polyphenols and antioxidant activity in functional food. Journal of Food Engineering 74: 416-423. http://dx.doi. org/10.1016/j.jfoodeng.2005.03.057
Seigler D.S., Seilheimer S., Keesy J., Huang H.F. 1986. Tannins from four common Acacia species of Texas and Northeastern Mexico. Economic Botany 40: 220-232. http://dx.doi.org/10.1007/ BF02859146

Sidjimova B., Evstatieva L., Ivanova A., Mechkarova P., Lazarova I., Tchorbanov B. 2011. Intraspecific variability of main phytochemical compounds in Tribulus terrestris L. from North Bulgaria. Biotechnology and Biotechnological Equipment 25: 2348-2351. http://dx.doi.org/10.5504/ BBEQ.2011.0036

Singleton V.L., Kratzer F.H. 1973. Plant Phenolics. In: Toxicants Occurring Naturally in Foods. National Research Council, National Academy of Sciences, Washington, pp. 309-345.

Smallwood P.D., Peters W.D. 1986. Grey squirrel food preferences: the effects of tannin and fat concentration. Ecology 67: 168-174. http://dx.doi. org/10.2307/1938515

Southwood T.R.E. 1961. The number of species of insect associated with various trees. Journal of Animal Ecology 30: 1-8. http://dx.doi. org/10.2307/2109

StatSoft Inc. STATISTICA (data analysis software system), version 7.1. 2005, http://statsoft.com.

Tardío J., Pardo-de-Santayana M., Morales R. 2006. Ethnobotanical review of wild edible plants in Spain. Botanical Journal of the Linnean Society 152: 27-71. http://dx.doi.org/10.1111/j.10958339.2006.00549.x

Trimble H. 1896. The tannin of some acorns. American Journal of Pharmacology 68: 601-604.

Turner N.J., Łuczaj Ł.J., Migliorini P., Pieroni A., Dreon A.L., Sacchetti L.E., Paoletti M.G. 2011. Edible and tended wild plants, traditional ecological knowledge and Agroecology. Critical Reviews in Plant Sciences 30: 198-225. http://dx.doi.org/10. 1080/07352689.2011.554492

Weckerly F.W., Sugg D.W., Semlitsch R.D. 1989. Germination success of acorns (Quercus): insect predation and tannins. Canadian Journal of Forest Research 19: 811-815. http://dx.doi. org/10.1139/x89-124

Ziołowy Zakątek. Mąka z żołędzi. http://www.ziolowyzakatek.sklep.pl/maka.z.zoledzi.eko.1kg.dary. natury.html 